\title{
Social and Emotional Development Among Gifted Students: Enhancing Decision Making Skills And Resilience
}

Nor Hamizah bt Ab Razak, Abdul Rashid bin Abdul Aziz, Siti Nubailah bt Mohd Yusof

To Link this Article: http://dx.doi.org/10.6007/IJARBSS/v11-i1/9018

DOI:10.6007/IJARBSS/v11-i1/9018

Received: 03 November 2020, Revised: 05 December 2020, Accepted: 14 January 2021

Published Online: 26 January 2021

In-Text Citation: (Razak et al., 2021)

To Cite this Article: Razak, N. H. bt A., Aziz, A. R. bin A., \& Yusof, S. N. bt M. (2021). Social and Emotional Development Among Gifted Students: Enhancing Decision Making Skills And Resilience. International Journal of Academic Research in Business and Social Sciences, 11(1), 970-977.

Copyright: (c) 2021 The Author(s)

Published by Human Resource Management Academic Research Society (www.hrmars.com) This article is published under the Creative Commons Attribution (CC BY 4.0) license. Anyone may reproduce, distribute, translate and create derivative works of this article (for both commercial and non-commercial purposes), subject to full attribution to the original publication and authors. The full terms of this license may be seen at: http://creativecommons.org/licences/by/4.0/legalcode

Vol. 11, No. 1, 2021, Pg. 970 - 977

Full Terms \& Conditions of access and use can be found at http://hrmars.com/index.php/pages/detail/publication-ethics 


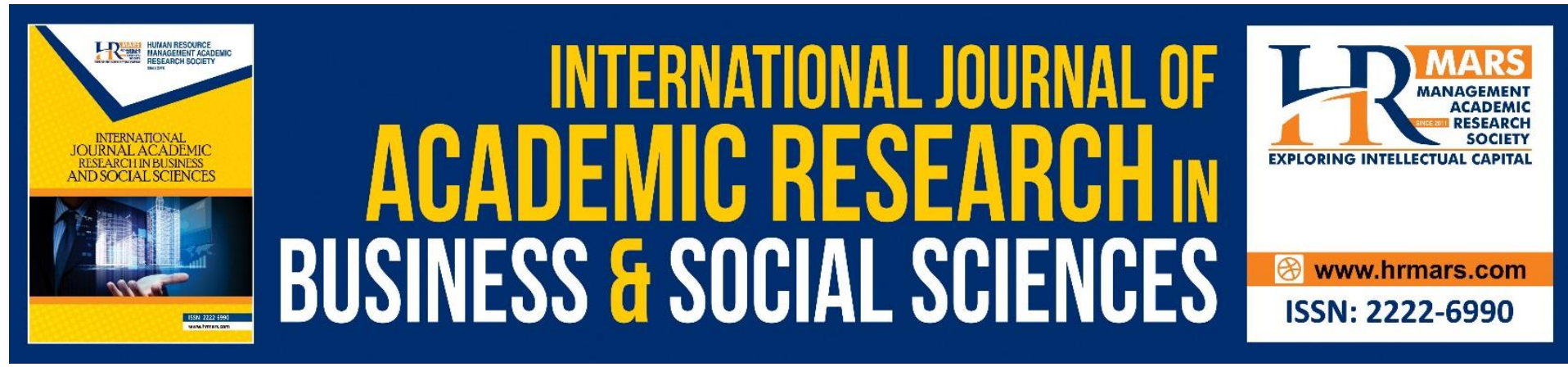

\title{
Social and Emotional Development Among Gifted Students: Enhancing Decision Making Skills And Resilience
}

\author{
Nor Hamizah bt Ab Razak, Abdul Rashid bin Abdul Aziz, Siti \\ Nubailah bt Mohd Yusof \\ Universiti Sains Islam Malaysia, Malaysia
}

\begin{abstract}
Social- emotional issues and gifted and talented students (GTS) are inseparable. Guidance for managing social and emotional issues among GTS is crucial to optimally promote student progress and stimulate excellence in the country. This study aims to reveal the need to improve decision making skills and resilience among GTS which is also a strategic approach to helping these groups managing their social and emotional issues. In the meantime, counselors are the best profesional helper and they have to play an important role in helping the GTS for improving their skills and abilities thus helping them deal with social and emotional issues.
\end{abstract}

Keywords: Gifted and Talented Student, Social and Emotional Issues, Decision Making Skills, Resilience.

\section{Introduction}

Generally, gifted and talented students (GTS) are individuals who have the advancement of developmental aspects such as physical, psychomotor, emotion, spiritual, intellectual and social as compared to ordinary students (Touron, Touron \& Silvero, 2005). In Malaysia, GTS is identified through the Permata Negara program, which draws on the concept of gifted and talented students in line with the goal of the National Education Philosophy which is a pillar in the development of human capital (Siti et al., 2012). Similarly, in other countries around the world have their own ways in identifying GTS and used different testing instrument and procedures. Although these groups are better known as individuals with intellectual excellence, creativity and high-efficiency of problem solving (Rorlinda, 2014), they are also struggling with social and emotional issues (Versteynen, 2013; Rosadah et al., 2009; Abu Yazid \& Aliza, 2009; Aliza \& Hamidah, 2009) which leads to barriers for them to grow optimally. Internal and external studies have revealed the types of social and emotional issues among GTSs such as emotional intensity, perfectionism, high concern, high sensitivity, overexcitability, sensitivity to the high social justice, high self-criticism, difficulty in adaptation to the new environment, and lack of social and communication skills (Abu \& Noriah, 2016; Fouladchang, Kohgard \& Salah 2010; Rosadah et al, 2009). In the meantime, Scott (2012) and Abu \& Aliza (2009) suggested these issues are said to arise due to factors such as asynchronous development, high expectations from various parties, difficult to adapt to social 
interaction and so on. These issues also are found to contribute to the problem of low selfesteem, low self-motivation, underachievement and anxiety (Rorlinda et al., 2016).

The above points explain the social and emotional issues have a great impact on the development of the GTS in terms of mental health as well as academic abilities. Therefore, GTS requires appropriate knowledge, skills and abilities as a strategic step in addressing the social and emotional issues faced (Java, 2014; Mann, 2006). In dealing with the issue, decision making skills and resilience are seen as the exact elements that need to be enhanced among themselves. This is because the skills and abilities have relationships with each other (Coscun et al, 2014) and are highly demanded in handling social and emotional issues (Cazan \& Dumitrescu, 2016). Thus, by having decision making skills and resilience, GTS is able to tackle and manage the social and emotional issues while furthering development to the optimum levels.

Consequently, Colengelo (2002) suggests a major helper of importance in helping GTS are counselors, especially school counselors. According to him, counselors have qualified qualifications in serving the students. In addition, they are also trained to implement a comprehensive development program that can improve GTSs achievement and provide guidance in terms of career, academic and personal issues. Therefore, it is the roles of counselors to help in improving decision making skills and resilience among GTS. For this reason, one of the best approaches to be offer by school counselor is providing counseling services (Noriah \& Yazid, 2010).

\section{Decision Making Skills}

Rehman \& Khan (2015) has defined decision making as the process of selecting one possibility from other possibilities. Decision making is also a skill that involves critical cognitive processes and is used in any situation in everyday life (Zakri \& Saemah, 2015). In addition, this skill also can be learned and polished (Mincemoyer \& Perkins, 2003) and is able to contribute to enhancing self-esteem, life satisfaction and ability to cope with stress (Colakkadioglu, 2016). A study on decision making skills among GTS has been carried out aggressively in the west. However, in Malaysia the specific study on this skill has not been widely disseminated. However, from studies on GTS in Malaysia such as studies on leadership level (Rorlinda, 2014), social skills (Noriah, Mohd \& Abu, 2014), cognitive processing profile (Rosadah, Noriah \& Zalizan, 2005) explaining generally the level of decision making skills among GTS is high. Likewise with overseas studies, most researchers explain the decision making skills of this group is high (Saygili, 2014; Ball et al., 1994; Davidson \& Sternberg, 1984). In contrast, Milgram (1991) argues that GTS have problem in making decision because of some excel in many areas. Meanwhile, there are also many studies suggesting that the skill level of GTS should be upgraded (Ozcan \& Zaaroglu, 2017; Mofield et al., 2016). Accordingly, Schlichter (1981) also sees the importance of decision making skills among GTSs to offset their needs and abilities and this skill should be instilled on this group. It also coincides with the concept of the skill itself that can be taught, honed and polished (Mincemoyer \& Perkins, 2003) which in turn makes decision skills as a necessity for this group.

In addition, Ersoy \& Deniz (2016) explains that decision making skills among GTSs need to be improved continuously because the unique features of the GTS itself can make the skills weak. For example, one of the unique features of GTS is extreme perfectionist. This feature has put this group under pressure or anger if they are unable to do something perfectly as expected. This perfectionism has prompted the GTS not to think about alternatives in making decisions but instead acting without thinking of the difference between right and wrong. It explains, 
though most think that decision making skills among GTS are high, but it should be noted that such skills can be challenged. Therefore, the skill must be taught from time to time.

\section{Resilience}

Resilience in a person can act as a defense fortress from falling down when exposed to adversity or stress. According to Fredrickson (2004), resilience is an ability for an individual to rise from sadness or difficulty. In fact, the individual will also recover by rebounding all the difficulties faced and able to continue to thrive (Chen et al., 2017).

Meanwhile, Neihart (2002) suggests that the characteristics of gifted students are as characteristic of the students of high resilience. They are more likely to have a high level of emotional intelligence, self-efficacy, curiosity, ability to solve problems and so on. Meanwhile, Cazan \& Dumitrescu (2016) argue that resilient GTS is a student capable of addressing challenges in life. In addition, they also make life's difficulties as a challenge regardless thinks the matter as a problem or a barrier to be more advanced. Although most studies on GTS explain this group have high resilience, but Bland et al (1994) reveals that there is also GTS which has low resilience. This is not only a big loss for the GTS itself but it also hurts the country as the GTS is the most important asset of the country. In conformity with Noriah and Abu (2010), the GTS is the most important asset of the nation that needs to be reflected in their potential for excellence in national development. Thus, Bland et al. (1994) emphasized the importance of research on resilience among GTS.

In the meantime, Pfeiffer \& Stocking (2000) also argued that although the GTS is more likely to exhibit academic abilities and better known as efficient students in problem solving and creative, they are also susceptible to pain, difficulty and psychological problems. The findings were supported by the findings from Kline and Short (1991) that found the resilience level of gifted student was inversely proportional to the level of emotional problems. He also revealed that the level of GTS resilience decreased when class grades shifted due to increased emotional problems among them.

\section{Counseling Service}

Counseling service is responsible for providing support at the school level that helps meet the needs of the GTS. According to Wood (2010), GTS group is considered unique and elusive and they need a careful observation. The extraordinary intellectual abilities compared to other teenagers (Noriah \& Abu, 2010) have led this group to require special attention and needs which include academic, career, life and psychosocial (Rorlinda et al., 2016).

As ordinary teens, the GTS is also under pressure in development as a teenager in this challenging world. Many studies in Malaysia have found that counseling services are indispensable for GTS (Abu Bakar \& Noriah, 2010; Rafidah, 2013). However, most students who get counseling do not express issues related to the psychological problems they encounter as gifted learners. Those present are just to get counseling on career issues or get advice on academic issues only. This clearly shows that the GTS often solicits counseling services but is not ready or embarrassed to express issues related to their unique psychological issues.

In addition, most Malaysian counselors are not exposed or have no special training in relation to the GTS. Supposedly, school counselors should be able to proactively providing services to all students (ASCA, 2005). Therefore, to meet all types of student counselors must understand the strengths and challenges of all types of students including GTS. In this regard, the counselor must be prepared with the knowledge especially on the development of the GTS. 
Additionally, counselors should also apply the counseling skills they possess in enhancing the existing potential of counselors (Wood 2010). Furthermore, in order to make the services rendered effectively, counselor should provide different services to ordinary students. The GTS requires services involving creative approaches that coincide with unique cognitive and effective development (Wood, 2010).

\section{Conclusion}

In conclusion, the discussion explains the skills of decision making and resilience as elements that can help GTS in addressing the social and emotional issues faced and that elements can be learned and enhanced through a systematic method. According to Coscun et al. (2014), decision making variables are closely related to the resilience variables. Individuals with high decision making skills also have a high level of resilience. On the other hand, those who are low level decision making skills are difficult to deal with all the issues faced and do not have the ability to keep up. Consequently, counselors need to play a role in helping GTS improve their skills and abilities in addressing social and emotional issues effectively. The appropriate services medium for GTS is counseling services, where GTS can sharpen their skills and intelligence from the service.

Looking at the importance of improving the decision making skills and the capabilities of the GTS as well as the unique features of this group, it is imperative to identify appropriate service approaches to these groups. Therefore, studies related to the GTS approach should be highlighted by future researchers in efforts to improve their decision making skills and resilience. In addition, it is recommended that creative approaches such as play therapy approaches should be highlighted in an effort to help GTS in view that play therapy is a therapeutic approach richen by creative elements (Sarpoulaki \& Kolahi, 2016). The matter also corresponds to Moon (2002) view that encourages counselors to explore effective techniques or strategies for applying to the GTS. Even the merger of counseling theories with various appropriate therapies enables clients to get literate faster (Paw, Noriah and Salleh 2008).

The efforts and suggestions discussed above are seen as one of the most effective strategies to address social and emotional issues among GTS. It not only helps to improve the level of GTS life that is categorized in special needs teens but also develops counseling services roles in schools in helping the GTS. Hence, this study is expected to raise public awareness on GTS issues and provide exposure to professional practitioners, especially counselors on management strategies on social and emotional issues among GTS.

\section{Corresponding Author}

Nor Hamizah bt Ab Razak,

Faculty of Leadership and Management Universiti Sains Islam Malaysia

Email: norhamizah@usim.edu.my

\section{References}

Abu, Y. A. B., \& Noriah, M. I. (2016). Pendidikan pintar dan berbakat di Malaysia. Penerbit Universiti Kebangsaan Malaysia. Bangi.

Abu, Y. A. B., \& Aliza, A. (2009). Sokongan psikologikal dan sosio-emosi pelajar pintar cerdas. In Noriah M.I., Rosadah A.M. \& Siti Fatimah M.Y. (Eds.), PERMATApintar: Pengalaman UKM. Bangi: UKM. 
Aliza, A., \& Hamidah, Y. (2009). Ciri-ciri kanak-kanak pintar cerdas. PERMATApintar Negara: Pengalaman UKM. Bangi: Pusat PERMATApintar Negara.

American School Counselor Association. (2005). The ASCA National Model: A framework for school counseling programs (2nd ed.). Alexandria, VA: Author.

Ball, C., Mann, L., \& Stamm, C. (1994). Decision-Making Abilities of Intellectually Gifted, Australian Journal of Psychology, 46(1), 13-20.

Bland, L. C., Sowa, C. J., \& Callahan, C. M. (1994). An Overview of Resilience in Gifted Children. Roeper Review, 17(2), 77-80.

Cazan, A., \& Dumitrescu, S. A. (2016). Exploring The Relationship Between Adolescent Resilience, Self-Perception and Locus Of Control. Romanian Journal of Experimental Applied Psychology, 7(1), 283-286.

Chen, X., Cheung, H. Y., Fan, X., \& Wu, J. (2017). Factors related to resilience of academically gifted students in the chinese cultural and educational environment. Psychology in the Schools, (1), 1-13.

Colakkadioglu, O., \& Celik, B. (2016). The effect of decision-making skill training programs on self-esteem and decision-making styles. Eurasian Journal of Educational Research, $65,259-276$.

Colangelo, N. (2002). Counseling gifted and talented students. The National Research Center on the Gifted and Talented Newsletter. Retrieved from http://www.gifted.uconn.edu/nrcgt/newsletter/fall02/fall022.html.

Coskun, Y. D., Garipağaoğlu, C., \& Tosun, U. (2014). Analysis of the Relationship between the Resiliency Level and Problem Solving Skills of University Students, Procedia - Social and Behavioral Sciences, 114, 673-680.

Davidson, J., \& Sternberg, R. (1984). The role of insight in intellectual giftedness. Gifted Child Quarterly, 28, 58-64.

Ersoy, E., \& Deniz, M. E. (2016). Psychometric Properties of the Gifted Students' Coping with Anger and Decision Making Skills Scale. Journal of Education and Practice, 7(15), 121-128.

Fouladchang, M., Kohgard, A., \& Salah, V. (2010). A study of psychological health among students of gifted and nongifted high schools. Procedia - Social and Behavioral Sciences, 5(2), 1220-1225.

Frederickson, B. L. (2004). The Broaden-and-Build Theory of Positive Emotions. Philosophical Transactions of the Royal Society, 359, 1367-1377.

Java, L. A. (2014). Problem Solving Strategies and Metacognitive Skills for Gifted Students in Middle School. Retrieved from https://digitalcommons.Isu.edu/gradschool_theses/1872.

Kline, B. E., \& Short, E. B. (1991). Changes in emotional resilience: Gifted adolescent females. Roeper Review,13(3), 118-121.

Mann, R. L. (2006). Effective Teaching Strategies for Gifted/Learning-Disabled Students with Spatial Strengths. The Journal of Secondary Gifted Education, 2, 112-121.

Milgram, R. M. (1991). Counseling Gifted and Talented Children: A Guide for Teachers, Counselors and Parents, Ablex Piblishing Corporation Norwood, New Jersey.

Mincemoyer, C. C., \& Perkins, D. F. (2003). Assessing decision making skills of youth. The Forum for Family and Consumer Issues, 8(1).

Mofield, E., Parker, P. M., \& Chakraborti, G. S. (2016). Perfectionism, Coping, and Underachievement in Gifted Adolescents: Avoidance vs. Approach Orientations. Education Sciences, 6(3), 21. 
Moon, S. M., Kelly, K. R., \& Feldhusen. (1997). Specialized counseling services for gifted youth and their families: A needs assessment. Gifted Child Quarterly, 41, 16-25.

Neihart, M. (2002). Risk and resilience in gifted children: A conceptual framework. In M. Neihart, S. Reis, N.M. Rob- inson, \& S.M. Moon (Eds.), The social and emotional development of gifted children: What do we know? (pp. 113-124). Waco, Texas: Prufrock Press, Inc.

Noriah, M. I., \& Abu, Y. A. B. (2010). Psychological issues and the need for counseling services among Malaysian gifted students. Procedia - Social and Behavioral Sciences, 5(2), 665-673.

Noriah, M. I., Mohd, H. Z. A., \& Abu, Y. A. B. (2014). Dimensions of Social Skills and their Relationship with Empathy among Gifted and Talented Students in Malaysia. Procedia - Social and Behavioral Sciences, 116(2003), 750-753.

Ozcan, D., \& Zaaroglu, L. (2017). Determination of The Relationship Between Strategies of Decision-Making And Emotional Intelligence Of Gifted Students. ENSAYOS, Revista de la Facultad de Educación de Albacete, 32(2), 77-95.

Paw, E. S., Noriah, M. I., \& Salleh, A. (2008). Lukisan sebagai proses diagnosis dan intervensi rawatan dalam sesi kaunseling. Jurnal PERKAMA,14,1-22.

Pfeiffer, S. I., \& Stocking, V. B. (2000). Vulnerabilities of academically gifted students. Special Services in the Schools, 16(1-2), 83-93.

Rafidah, K., \& Noriah, M. I. (2013). Terapi seni dalam kaunseling pelajar pintar dan berbakat. Malaysian Journal of Youth Studies, 8(6), 147-166.

Rehman, R. R., \& Khan, A. W. (2015). Realting individual demographics, work- family conflict and decision making styles of faculity members in higher education sector of Pakistan. VFAST Transections on Education and Social Sciences, 5, 51-63.

Rorlinda, Y. (2014). Ciri- ciri kepimpinan pelajar pintar dan berbakat: Implikasi ke atas kepimpinan remaja Islam. International Journal of Islamic Thought, 6, 57-70.

Rorlinda, Y., Noriah, M. I., Aishah, S. H., \& Radzi, A. M. (2016). Kajian Jatidiri dan Tekanan Isu Sosio-Emosi dalam Kalangan Pelajar Pintar dan Berbakat. Jurnal Psikologi Malaysia, 30(2), 42-60.

Rosadah, A. M., Noriah, M. I., \& Melor, M. Y. (2009). Kepintaran dan pintar cerdas berbakat: Definisi dan makna. Dalam PERMATApintar Negara: Pengalaman UKM. Pusat PERMATApintar Negara. Universiti KebangsaanMalaysia. Bangi.

Rosadah, A. M., Noriah, M. I., Zalizan, M. J. (2005) Profil pemprosesan kognitif pelajar pintar cerdas akademik di sekolah menengah. Jurnal Pendidikan Malaysia, 30, 35-49.

Saygili, G. (2014). Problem-Solving Skills Employed by Gifted Children and Their Peers in Public Primary Schools in Turkey. Society for Personality Research, 42, 53-64.

Schlichter, C. L. (1981). Decision Making: An Instructional Strategy for the Rural Gifted Student. Retrieved from http://files.eric.ed.gov/fulltext/ED220257.pdf.

Scott, M. T. (2012). Socio-Emotional and Psychological Issues and Needs of Gifted AfricanAmerican Students: Culture Matters. Interdisciplinary Journal of Teaching and Learning, 2, (1), 23-33.

Siti, F. M. Y., Noriah, M. I., Melor, M. Y.,\& Rosadah, A. M. (2012), The Identification of Gifted and Talented Students. Procedia - Social and Behavioral Sciences, 55, 585 - 593.

Touron, J., \& Silvero, M. (2005). The Center for Talented Youth Spain: An initiative to serve highly able students. High Ability, 15, 121-135.

Versteynen, L. (2013). Issues in the social and emotional adjustment of gifted children: What does the literature say?. The New Zealand Journal of Gifted Education,13 (1). 
Wood, S. (2010). Best practices in counseling the gifted in school: What's really happening. Gifted Child Quarterly, 54 (1), 42-58.

Zakri, A., \& Saemah, R. (2015). Kemahiran Meta-Tingkah Laku dan Kemahiran Membuat Keputusan Pelajar Bermasalah Disiplin dan Tidak Bermasalah Disiplin. Jurnal Pendidikan Malaysia, 40(2), 175-183. 